\title{
Effect of Brainstorming Program on Teaching Skills for Student's Teacher
}

\author{
Amira Gharib Kotb ${ }^{1}$ \\ ${ }^{1}$ Lecturer at the Department of Curriculum and Teaching Methods and Field Training, Faculty of Physical Education for Girls, \\ Zagazig University, Egypt
}

\begin{abstract}
This research aims to design a proposed program using brainstorming strategy. This research also aims to identify the effect of brainstorming program on teaching skills for student's teacher. Two groups were selected from female students of third class in faculty of physical education, Zagazig University, (experimental group $n=25$ (EG) and control group $n$ $=25(C G))$ were selected for this purpose and (15) students for Expeditionary study, Teaching skills variables were randomly assigned (Personal skills, Preparation and processing of lesson venue, Instructional instruments' utility, Planning and executing lesson: [Introduction and warm-up, Physical preparation, Educational and practical activity, Final activity], Correction, Total of axes of teaching skills for student's teacher list). Results: (1) Proposed brainstorming program has a positive effect on teaching skills for experimental group. (2) Traditional method (oral explanation and practical model) has a positive effect on teaching skills for control group. (3) Brainstorming program is better than traditional method on teaching skills improvement, which indicates the effectiveness of brainstorming program.
\end{abstract}

Key words: brainstorming - teaching skills - student's teacher

\section{Introduction}

$\mathrm{R}$ esearchers all over the world are concerned with students as they are the future of scientific and practical application of educational curricula prepared by them.

The globe is turning to be a small village, due to the developments in the scientific, economic and social aspects of life as well as the communication revolution results from the knowledge development and globalization. As a response to those developments and challenges it was necessary to prepare a generation that capable of confronting those challenges through changing the traditional methods of learning and teaching as well as focusing on providing students with the suitable training on different thinking styles (Richard, A., Schmidt, 2001).

Brainstorming strategy is one of the most important strategies in provoking creativity and solving problems in the educational, commercial, industrial and political fields. Brainstorming strategy was introduced by Alex Osborn, an American advertisement company manager in 1938 as a results of his inconvenience of traditional business meetings. Brainstorming means the use of brain to the active problem solving and the brainstorming session aims to develop creative solutions to problems (Jarwan, 2005).

The major purpose of brainstorming as a teaching strategy is to foster and enhance communication skill, help to promote thinking and decision-making skill as well as foster different viewpoints and opinions. It may equally be used in all key areas of learning. However, the major limitation is that it is generally not suitable for younger levels because of the level of reasoning required in order for it to work. The teacher must equally be able to guide and give aid as necessary considering the class environment as such considerations often determine the outcomes. In brainstorming techniques, the instructor carefully plans the lesson to reach the desired learning outcomes. The group interacts in response to questions, and the instructor refrains from entering the discussion as an active participant. Students are encouraged to learn about the subject by actively sharing information, experiences, and opinions. The flow of communication is a transaction among all the students rather than recitation and response between individual students and the instructor (Beebe, SA, Masterson, J.T., 2003), (Abd Elrazek Mokhtar, 2004).

This research aims to design a proposed program using brainstorming strategy. This research also aims to identify the effect of brainstorming program on teaching skills for student's teacher. 


\section{Procedures}

\section{The research sample}

The study was designed to design an educational program using brainstorming on teaching skills for student's teacher, aged 20-22 years old. Two groups were selected from female students of third class in faculty of physical education, Zagazig University, (experimental group $n=25$ (EG) and control group $n=25$ (CG)) were selected for this purpose and (15) students for Expeditionary study.

Table 1

Research sample

\begin{tabular}{|c|c|c|c|c|c|}
\hline \multirow{2}{*}{ Variables } & \multirow{2}{*}{ Research Sample } & \multirow{2}{*}{ Total Sample } & \multicolumn{3}{|c|}{ Sample } \\
\cline { 3 - 6 } & & & Experimental & Control & Pilot \\
\hline Fourth class students & 137 & 65 & 25 & 25 & 15 \\
\hline$\%$ & 100 & 47.45 & 18.25 & 18.25 & 10.95 \\
\hline
\end{tabular}

The subjects were randomly assigned $(\mathrm{n}=65$ : age, $21.87 \pm$ 0.482 years old; weight, $65.54 \pm 4.612 \mathrm{~kg}$ and height, $164.16 \pm 4.986 \mathrm{~cm}$ ), respectively (Mean \pm SD). Mental ability were $82.63 \pm 2.6$ degree, respectively (Mean $\pm \mathrm{SD}$ ). Teaching skills variables were randomly assigned (Personal skills, Preparation and processing of lesson venue, Instructional instruments' utility, Planning and executing lesson: [Introduction and warm-up, Physical preparation, Educational and practical activity, Final activity], Correction, Total of axes of teaching skills for student's teacher list) $6.93 \pm 0.512$ degree, $4.86 \pm 0.251$ degree, $3.78 \pm 0.229$ degree, $7.53 \pm 0.262$ degree and $13.56 \pm 0.274$ degree, $17.75 \pm 0.318$ degree, $8.56 \pm 0.261$ degree, $5.33 \pm 0.265$ degree, $68.3 \pm 1.039$ degree, respectively (Mean $\pm \mathrm{SD}$ ).

\section{Data collection:}

\section{Mental ability test:}

Mental test for (15-17) years old prepared by Faruok Abd Alfattah Musa (2009) was administered in a group. Thirty minutes and 90 questions were allowed for the completion of the test.

\section{Teaching skills for student's teacher list:}

Survey to determine teaching skills for student's teacher list were used to design an educational program using brainstorming in order to develop teaching skills for student's teacher, as following: (1) course content analysis, (2) determine teaching skills bifurcation.

The exploratory trial was performed on (15) students on $10 / 02 / 2015$ till $14 / 02 / 2015$. The goal of this trial was to avoid all errors that may occur in the main trial such as the expected time for work, response of the assistant working team and students at application in addition to the method used in test application.
Factor of validity:

Internal consistency and sincerity was used, it transpired that the internal consistency of significant scientific processing of phrases, to learn which shows correlation of the phrases under discussion.

\section{Stability coefficient:}

The researcher applied the test method (Cronbach's alpha) correlation to calculate stability of phrases, ranging from the correlation coefficient between $(0.602,0.697)$ which indicates the high stability of the variables under consideration.

\section{Educational program:}

The brainstorming program was applied based on the following main principles:

1. Delaying evaluation (this means that evaluation of any ideas generated in the first stages of the session is not allowed).

2. Freedom of thinking (liberating from any blocks against creative thinking, increasing creative abilities of imagination and ideas generation in an atmosphere that is open for criticism and evaluation).

3. Quantity before quality (concentration in the brainstorming session on generating the biggest possible amount of ideas whatever their qualities are).

4. Building on others' ideas (it is allowed to develop ideas of the others and generate new ideas proposed as a legitimate right for any participant to change them and generate other ideas with us).

The researcher performed the pre-measures on 17/02/2015 up to 21/02/2015 for the experimental group (brainstorming) and the control group (traditional program). Started by applying the specific educational program by brainstorming program for experimental group and control group for a period of (8) week at the rate of (2) sessions per week and (45) minutes per session, and until 
$21 / 04 / 2015$, up to $25 / 04 / 2015$ the researcher performed the post measures.

Statistical methods:
The researcher used the SPSS 15.0, statistical program for data processing.

Results

Table 2

Difference significance of experimental group (brainstorming) in teaching skills

$\mathrm{N}=25$

\begin{tabular}{|c|c|c|c|c|c|c|c|c|}
\hline \multirow{2}{*}{\multicolumn{2}{|c|}{ Variables }} & \multirow{2}{*}{ Unit } & \multicolumn{2}{|c|}{ Pre } & \multicolumn{2}{|c|}{ Post } & \multirow{2}{*}{ DA } & \multirow{2}{*}{ T-stat } \\
\hline & & & Mean & SD & Mean & SD & & \\
\hline & Personal skills & Degree. & 6.94 & 0.514 & 10.02 & 1.425 & 3.08 & $9.96^{*}$ \\
\hline \multicolumn{2}{|c|}{$\begin{array}{c}\text { Preparation and processing of lesson } \\
\text { venue }\end{array}$} & Degree. & 4.84 & 0.247 & 7.24 & 0.874 & 2.40 & $12.95 *$ \\
\hline \multicolumn{2}{|c|}{ Instructional instruments' utility } & Degree. & 3.80 & 0.232 & 6.39 & 1.246 & 2.57 & $9.93^{*}$ \\
\hline \multirow{4}{*}{ 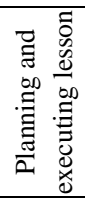 } & Introduction and warm-up & Degree. & 7.51 & 0.258 & 10.13 & 0.928 & 2.62 & $13.33 *$ \\
\hline & Physical preparation & Degree. & 13.59 & 0.278 & 16.29 & 1.361 & 2.70 & $9.52 *$ \\
\hline & $\begin{array}{l}\text { Educational and practical } \\
\text { activity }\end{array}$ & Degree. & 17.77 & 0.321 & 20.45 & 1.603 & 2.68 & $8.03 *$ \\
\hline & Final activity & Degree. & 8.57 & 0.263 & 10.40 & 0.721 & 1.83 & $11.68 *$ \\
\hline & Correction & Degree. & 5.36 & 0.268 & 8.12 & 1.142 & 2.76 & $11.53 *$ \\
\hline \multicolumn{2}{|c|}{$\begin{array}{l}\text { Total of axes of teaching skills for } \\
\text { student's teacher list }\end{array}$} & Degree. & 68.38 & 1.042 & 89.24 & 3.590 & 20.86 & $27.34 *$ \\
\hline
\end{tabular}

* Significantly different at $\mathrm{p}<.05=2.021 \quad \mathrm{DA}=$ Differences Average

Table (2) shows significant statistical differences at $\mathrm{p}<.05$ between pre and posttest in experimental group (brainstorming) in teaching skills (Personal skills, Preparation and processing of lesson venue, Instructional instruments' utility, Planning and executing lesson
"Introduction and

warm-up\Physical preparation\Educational and practical activity/Final activity" and Correction) in favor of the post measuring to the pre measuring.

Table 3

Difference significance of control group in teaching skills $\mathrm{N}=25$

\begin{tabular}{|c|c|c|c|c|c|c|c|c|}
\hline \multirow{2}{*}{\multicolumn{2}{|c|}{ Variables }} & \multirow{2}{*}{ Unit } & \multicolumn{2}{|c|}{ Pre } & \multicolumn{2}{|c|}{ Post } & \multirow{2}{*}{ DA } & \multirow{2}{*}{ T-stat } \\
\hline & & & Mean & SD & Mean & SD & & \\
\hline & Personal skills & Degree. & 6.91 & 0.511 & 8.29 & 1.683 & 1.38 & $3.84 *$ \\
\hline \multicolumn{2}{|c|}{$\begin{array}{c}\text { Preparation and processing of lesson } \\
\text { venue }\end{array}$} & Degree. & 4.87 & 0.255 & 6.21 & 1.476 & 1.34 & $4.38 *$ \\
\hline \multicolumn{2}{|c|}{ Instructional instruments' utility } & Degree. & 3.84 & 0.243 & 5.18 & 1.579 & 1.34 & $4.11 *$ \\
\hline \multirow{4}{*}{ 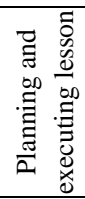 } & Introduction and warm-up & Degree. & 7.53 & 0.263 & 8.71 & 1.153 & 1.18 & $4.89 *$ \\
\hline & Physical preparation & Degree. & 13.54 & 0.272 & 15.10 & 1.489 & 1.56 & $5.05^{*}$ \\
\hline & $\begin{array}{c}\text { Educational and practical } \\
\text { activity }\end{array}$ & Degree. & 17.72 & 0.312 & 18.73 & 1.263 & 1.01 & $3.80^{*}$ \\
\hline & Final activity & Degree. & 8.61 & 0.287 & 9.32 & 1.260 & 0.71 & $2.69 *$ \\
\hline \multirow{2}{*}{\multicolumn{2}{|c|}{$\begin{array}{c}\text { Correction } \\
\text { Total of axes of teaching skills for } \\
\text { student's teacher list }\end{array}$}} & Degree. & 5.34 & 0.261 & 6.42 & 1.192 & 1.08 & $4.34 *$ \\
\hline & & Degree. & 68.36 & 0.892 & 77.96 & 2.593 & 9.60 & $17.15^{*}$ \\
\hline
\end{tabular}

* Significantly different at $\mathrm{p}<.05=2.021 \quad \mathrm{DA}=$ Differences Average

Table (3) shows significant statistical differences at $\mathrm{p}<.05$ between pre and posttest in control group in teaching skills (Personal skills, Preparation and processing of lesson venue, Instructional instruments' utility, Planning and executing lesson "Introduction and warm-up\Physical preparation\Educational and practical activitylFinal activity" and Correction) in favor of the post measuring to the pre measuring. 
Table 4

Difference Significance for Post Measures for Both Groups in teaching skills $\mathrm{N} 1=\mathrm{N} 2=25$

\begin{tabular}{|c|c|c|c|c|c|c|c|c|}
\hline \multirow{2}{*}{\multicolumn{2}{|c|}{ Variables }} & \multirow{2}{*}{ Unit } & \multicolumn{2}{|c|}{ experimental group } & \multicolumn{2}{|c|}{ control group } & \multirow{2}{*}{ DA } & \multirow{2}{*}{ T-stat } \\
\hline & & & Mean & SD & Mean & SD & & \\
\hline & Personal skills & Degree. & 10.02 & 1.425 & 8.29 & 1.683 & 1.73 & $5.44 *$ \\
\hline \multicolumn{2}{|c|}{$\begin{array}{c}\text { Preparation and processing of lesson } \\
\text { venue }\end{array}$} & Degree. & 7.24 & 0.874 & 6.21 & 1.476 & 1.03 & $4.16^{*}$ \\
\hline \multicolumn{2}{|c|}{ Instructional instruments' utility } & Degree. & 6.39 & 1.246 & 5.18 & 1.579 & 1.21 & $4.17 *$ \\
\hline \multirow{4}{*}{ 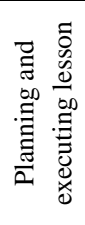 } & $\begin{array}{l}\text { Introduction and warm- } \\
\text { up }\end{array}$ & Degree. & 10.13 & 0.928 & 8.71 & 1.153 & 1.42 & $6.65^{*}$ \\
\hline & Physical preparation & Degree. & 16.29 & 1.361 & 15.10 & 1.489 & 1.19 & $4.09^{*}$ \\
\hline & $\begin{array}{c}\text { Educational and practical } \\
\text { activity }\end{array}$ & Degree. & 20.45 & 1.603 & 18.73 & 1.263 & 1.72 & $5.84 *$ \\
\hline & Final activity & Degree. & 10.40 & 0.721 & 9.32 & 1.260 & 1.08 & $5.15^{*}$ \\
\hline & Correction & Degree. & 8.12 & 1.142 & 6.42 & 1.192 & 1.70 & $7.14 *$ \\
\hline \multicolumn{2}{|c|}{$\begin{array}{c}\text { Total of axes of teaching skills for } \\
\text { student's teacher list }\end{array}$} & Degree. & 89.24 & 3.590 & 77.96 & 2.593 & 11.28 & $17.65^{*}$ \\
\hline
\end{tabular}

* Significantly different at $\mathrm{p}<.05=2.021 \quad \mathrm{DA}=$ Differences Average

Table (4) shows significant statistical differences at $p<.05$ between post measures for both groups experimental group (brainstorming) and control group in teaching skills (Personal skills, Preparation and processing of lesson venue, Instructional instruments' utility, Planning and executing lesson "Introduction and warm-up\Physical preparation\Educational and practical activitylFinal activity" and Correction) in favor of experimental group (brain storming).

\section{Discussion}

Improvement in posttest in experimental group is a result for ideas, proposals and mental activity sharing in order to generate ideas and collective brainstorming in the proposed program parts using brainstorming process, and it is a result to the educational program using brain storming style for female students.

These results are on line with studies of (Rashed Bn Husien Alabd Alkarem, 2008), (Naser Abd Elrazek Mohamed, 1999), (Zeynab Ahmed Mahmoud, 2013) that this may be attributed to the nature of brainstorming strategy as a collective discussion strategy that encourage students to generate the highest number of ideas that are varied and creative in a spontaneous and free open climate that is not critical and doesn't limit the freedom of launching ideas. Moreover, its nature based on phases allows students to move from one step to another freely after completing the previous step.

Improvement in posttest in control group is a result for traditional program cannot be unnoticed, as it depend on oral explanation and practical model of learned basic skills, motor duties gradient from easy to hard help gaining achievement and success, traditional program has a positive effect on skills (Eman Gamal Hafez, 2013), (Mostafa Ramadan Ahmed, 2013).

Rate of improvement in skills performance level of the experimental group which followed brainstorming method was better than rate of improvement in the same variables among the control group which followed traditional method (Akram Kamal Maamon, 2008).

These results are on line with studies of (Barnes, 2008), (Mohamed Saad Zaghlol, Hany Saeed Abd Elmonem, 2001) that proposed program using educational skills performance for student's teacher has a better effect than traditional method for student's teacher.

The most important, there are significant differences in favor of the experimental group that taught according to the proposed program.

The effect of this strategy in developing creative thinking as a whole and in its sub skills may be attributed to the advantages of this strategy that are accepted among students. Some of those advantages are the preparing element and making students ready to participate in the sessions as well as joy environment that provide students with a free climate that doesn't contain any critics and interference (Magdy Abo Bakr Hamza, 2013).

The findings of this study are Consistent with (Nonis, 2005), (Ahmed Abd Ellateef, 2001), (Naser Abd Elrazek Mohamed, 1999) that brainstorming strategy has a positive effect skills improvement.

\section{Conclusions}

(1) Proposed brainstorming program has a positive effect on teaching skills for experimental group. (2) Traditional method (oral explanation and practical model) has a positive effect on teaching skills for control group. (3) 
Brainstorming program is better than traditional method on teaching skills improvement, which indicates the effectiveness of brainstorming program.

\section{Recommendations}

Necessity of brainstorming program to improve teaching skills for student's teacher.

Interest in giving students a chance to express their own ideas in learning teaching skills which makes a strong motive to learn, increase their confidence when contact practical field outside scope of college.

Procedure more experimental researches on brainstorming style versus other teaching methods in order to prove its effectiveness in other fields.

Preparing proposed brainstorming programs to prepare teacher, because its positive effect on improvement of teaching skills level.

\section{References}

1. Abd Elrazek Mokhtar, (2004): brainstorming, concept principles and steps, Teacher Journal, Faculty of Education, Assiut University.

2. Ahmed Abd Ellateef Ebada (2001): Innovative solutions for theoretical and applied problems, Book Publishing Center, Cairo.

3. Akram Kamal Maamon (2008): Impact of brainstorming strategy on learning some basketball skills, Master Thesis, Faculty of Physical Education for Boys, Helwan University.

4. Barnes, JOSEPH, C., (2008): An Evolution of the competency Training of Students Teacher, PH. D., Diss, The pens-Sylvania state, UN.

5. Beebe, SA, Masterson, J.T., (2003): Communicating in small groups Principles and practices and practices, 3rd ed., Illinois Harper Collins publishers.

6. Eman Gamal Hafez (2013): Impact of brainstorming strategy by computer on development of motor innovation of sports shows, Master thesis, Faculty of physical education, Tanta University.
7. Jarwan, F. (2005). Teaching Thinking: Definition and applications. Amman: Dar Al-fkir. Jordan.

8. Rashed Bn Husien Alabd Alkarem (2008): brainstorming strategy, Ministry of Education, Kingdom of Saudi Arabia.

9. Magdy Abo Bakr Hamza (2013): Effect of brainstorming strategy on cognitive achievement of teaching curriculum and creative thinking for faculty of physical education, Trabols University, Faculty of physical education, Alexandria University.

10. Mohamed Saad Zaghlol, Hany Saeed Abd Elmonem (2001): Impact of proposed program for educational competencies performance on the improvement of some competencies of education during operation period of student's teacher (teaching division) in faculty of physical education in Tanta, Comprehensive Education Research Journal, Faculty of Physical Education for Girls, Zagazig University, 1:(2): 122-147.

11. Mostafa Ramadan Ahmed (2013): Effect of brainstorming on cognitive learning outcomes in volleyball, Master Thesis, Faculty of Physical Education for Boys, Helwan University.

12. Naser Abd Elrazek Mohamed (1999): The effectiveness of brainstorming strategy on mathematics learning in primary education, Master thesis, Scientific Journal, Faculty of Education, Aswan, South Valley University, 6,(13), 2-28.

13. Nonis, Aileen (2005): Technology and teacher preparation creating student involvement and creativity, University of Tennese, URL:www.smartakids.org/research/paper//.ASP.

14. Richard, A., Schmidt (2001): Motor learning and physical education. Human Kinetics books Champaign، III ions, USA.

15. Zeynab Ahmed Mahmoud (2013): Effect of brainstorming strategy in physical education lesson for female primary school, Master thesis, Faculty of physical education, Mansora University. 